Univerzitet u Beogradu
Poljoprivredni fakultet
Institut za poljoprivrednu tehniku
Naučni časopis
POLJOPRIVREDNA TEHNIKA
Godina XLV
Broj 2, 2020.
Strane: $45-55$

\title{
FEASIBILITY OF USING SAWDUST ASH OF Gmelina arborea ROXB., TREE IN ABIA STATE OF NIGERIA AS ADMIXTURE IN PRODUCTION OF CONCRETE
}

\author{
Oluwaseun Babalola $^{1 *}$, Michael Etteben ${ }^{2}$, Nkiru Ezejiofor $^{3}$, \\ Nnaemeka Nneji ${ }^{4}$, David Eze ${ }^{5}$, Francis Orji ${ }^{6}$, Augustine Igbozulike ${ }^{7}$ \\ 1, 2,4,5, 6, 7 Michael Okpara University of Agriculture, Umudike, Nigeria \\ ${ }^{3}$ National Agricultural Extension Research and Liaison Service, \\ Ahmadu Bello University, Zaria, Nigeria
}

\begin{abstract}
Gmelina arborea Roxb.,is a rainforest tree that is found in tropical region. The study investigates the feasibility and effect on the properties of concrete by using sawdust ash as pozzolan produced from Gmelina arborea Roxb.,tree in Abia state. Concrete mix of 1:2:4 by volume batching and constant water to cement ratio of 0.6 were used. The slumps were $60,70,89,60,55$ and $47 \mathrm{~mm}$ at partial replacement of 0,5 , $10,15,20$ and $25 \%$ respectively. The compressive strength at $28^{\text {th }}$ day of curing for 0,5 , $10,15,20$ and $25 \%$ were 27.67, 27.22, 21.22, 20.00, 18.89 and $18.33 \mathrm{~N} / \mathrm{mm}^{2}$ respectively. The research on the slump indicates that all the replacements have good workability to be categorized as true slump, with the $10 \%$ partial replacement having the highest workability. In addition, the compressive strengths developed at $28^{\text {th }}$ day showed that the concretes developed good strength, which can increase with further age of curing because pozzolanic concrete develops late better strength and durability than ordinary concrete.
\end{abstract}

\section{Keywords: Gmelina arborea Roxb., Sawdust Ash, Pozzolan, Concrete, Workability, Compressive Strength}

\section{INTRODUCTION}

Concrete is a composite material containing coarse and fine aggregates, bonded together by cement paste. Cement paste is a combination of cement and water, based on the water-cement ratio used in the concrete mix design. Cement is a binding agent in concrete mix, and it is the reliable binder since its discovery.

\footnotetext{
* Correspondeng author. E-mail address. ojedelestephen@gmail.com
} 
Portland cement is one of the types of cement used in construction industry, and it is classified as general purpose cement because of its numerous usages. It is widely used in developing countries.

Cement has deficiencies in some of its properties like setting time, workability in fresh concrete, compressive strength and durability in hardened concrete. Cement has some deficiencies in its usefulness, which are low workability of fresh concrete, compressive strength and durability. However, the production of cement is very expensive and causes pollution to the environment. The high cost of a bag of cement is caused by high capital intensive, high taxation of industry, fluctuations in power supply, policies of the government, high cost of transportation of cement etc. in order to achieve economic benefit in concrete production, the issue of high cost can be resolved if a partial replacement of cement with a cheap material that can blend with cement can be used as admixture in concrete batching and mixing. Materials that can be used as blended cement must be pozzolanic in nature or serve as superplasticizers.

Pozzolans are materials that can react with hydrated cement to form a cementitious compound. This cementitious compound reduces the permeability of concrete, thereby increasing the strength of concrete. Pozzolans have environmental, energy, economic and technical benefits than cement; hence its usefulness is very important in concrete production. According to [1], a material that meets minimum requirement of $70 \%$ of the sum of silica, alumina and iron oxide in composition meets the requirement to be used as pozzolan.

Researchers for several years are investigating into different materials that can replace or partially replace cement in concrete production. Pozzolans has been useful in concrete production since the period of Roman Empire with the use of roman concrete called opus caementicium, which is durable because it is incorporated with volcanic ash that can prevent the spreading of cracks as shown on the photo 1.

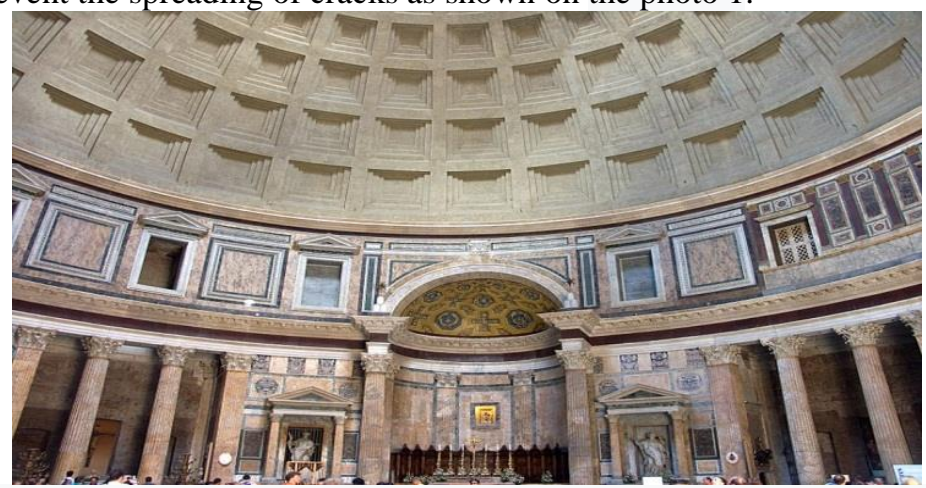

The photo 1. The Pantheon in Rome is an example of Roman Concrete Construction, [2].

There are two types of pozzolans, which are natural pozzolans (for example volcanic ash) and artificial pozzolans.

Artificial pozzolans can be divided into industrial and agricultural pozzolans. Many researches has been done by many researchers on agricultural residues to investigate their effect on concrete properties, such as corncob ash [3], sugar cain bagasse [4], groundnut shell ash [5], mollusc shell ash [6], Egg shell Powder [7] and rice husk ash [8, 9,10 and 11]. 
Saw dust ash materials possess pozzolanic properties, they impact technical advantages to the resulting concrete and also enable larger quantities of cement replacement to be achieved [12]. The primary aim of this study is to explore the potential of sawdust ash produced from one of products called Gmelina arborea Roxb., tree in Abia state of Nigeria as a partial replacement of ordinary Portland cement by blending it with cement in concrete production and examining its basic properties, like the workability and compressive strength of the concrete produced. The picture of Gmelina tree is shown in figure 2.

The technical benefits of pozzolans in concrete like better workability with low water cement ratio, resistant of concrete to sulphate attack and chloride attack can be improved with the presence of good pozzolan in concrete production.

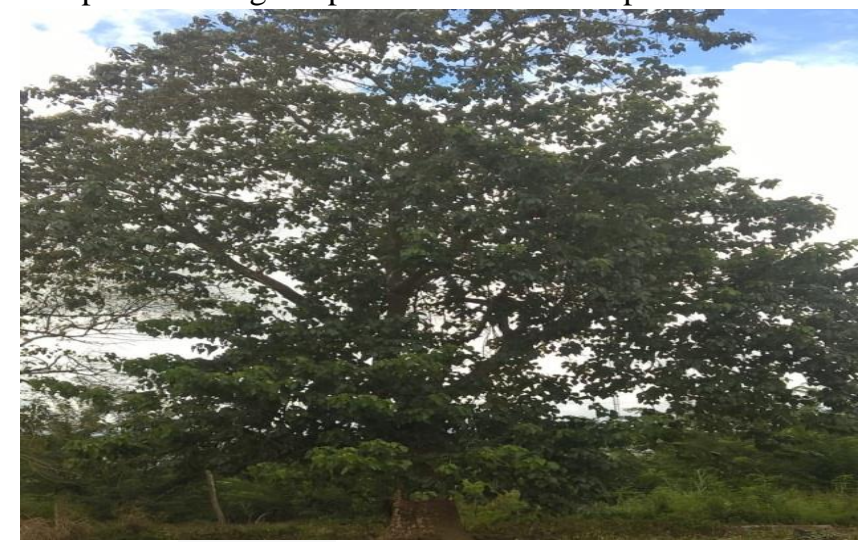

The photo 2. Gmelina arborea Roxb. tree

\section{MATERIALS AND METHOD}

\section{Materials and Equipment}

The materials that were used for the production of the concrete are: river sand, ordinary portland cement (OPC), saw dust ash from Gmelina arborea Roxb.,tree, borehole water, and granite. The equipment that were used are furnace, weighing balance, pycnometer bottle, density mould, compression machine, laboratory oven, mechanical sieve shaker, sieve brush, hand trowel, tamping rod, slump cone, curing tank, concrete cylindrical moulds, measuring tape, Sieve stack (British Standard) with receiver.

\section{Test Method}

A. sieve analysis of sand, gravel, cement and gmelina sawdust ash: In accordance with [13], river sand of size below $4.75 \mathrm{~mm}$ was used as fine aggregate; also coarse aggregate of size below $40 \mathrm{~mm}$ was used according to the recommended standard. The results of the sieve analysis on the aggregates are shown in tables 4.4 and 4.5 respectively. 
The Ordinary Portland cement (Dangote, Brand) that was used was obtained from a local supplier at army check point along Ikot Ekpene road in Umuahia Abia State and it conformed to the requirements of [14]. The gmelina tree saw dust used for this study was obtained by sawing the tree, using sawing machine and collected in saw mill points at timber market Ahiaeke, Umuahia, Abia State, Nigeria as shown in plate 3. The Sample was carefully collected to avoid mixing the saw dust with sand. The collected sample was burnt into ashes and the saw dust ash (SDA) was ground after cooling using mortar and pestle. The yield was used to calculate the average specific gravity of the gmelina sawdust ash. The water used for the study was obtained from CEET bore hole, MOUAU. The water was cleaned and free from any visible impurities. It conformed to [15] requirements. Generally, water that is suitable for drinking is satisfactory for use in concrete.

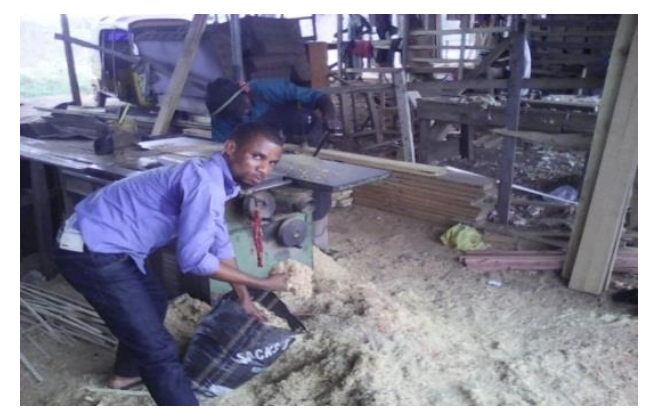

The photo 2. Collection of Gmelina arborea Roxb., Sawdust at Saw Mill Point

B. slump of fresh concrete: Slump test is used to determine the workability of fresh concrete. The method for slump test of fresh hydraulic-cement concrete in accordance with [16] was used to carry out the concrete slump test.

C. water absorption and compressive strength of hardened concrete

\section{Mix Proportion}

Concrete mix of ratio 1:2:4 was used to achieve concrete grade of $\mathrm{C} 25$ according to [17], with the use of water to cement ratio of 0.6 .

\section{Casting, Curing and Testing}

A. Water Absorption of Concrete after the Curing Period: The composites were made with materials having different water absorption rate, and bulk weight respectively.

The percentage absorption for the different sample replacement was then obtained and recorded according to the test method recommended by [18].

B. Procedures of compressive strength tests: [19] method for compressive strength tests were used for the concrete cubes mixtures to test all the concrete cubes.

Batching and casting were done with concrete mix of 1:2:4 at control level $(0 \%$ partial replacement) and 5 to $25 \%$ partial replacement of OPC with the pozzolan (Gmelina sawdust ash) to form Portland Pozzolanic Cement (PPC). 
The fresh concretes produced were used to fill the steel moulds of dimension 150x150x150mm to form concrete cubes, and de-moulding was done after 24 hours. The samples were allowed to undergo curing, and the samples were removed for testing. Concrete cubes of $150 \times 150 \times 150 \mathrm{~mm}$ cured at 7 days interval were crushed to determine their strength using a compressive machine of $2000 \mathrm{kN}$ capacity. Immerse in water, for a minimum of 5 minutes, those cubes which have not been cured in water or where the surfaces have been allowed to dry. The cubes were removed from the curing water tank for testing while they were still wet. Carefully, the cubes were centered on the lower platen and ensured that the loads were applied to the two opposite cast faces of the cube. Without shock, the load was applied and increased continuously at a nominal rate within the range $12 \mathrm{MPa} / \mathrm{min}$. to $24 \mathrm{MPa} / \mathrm{min}$. until no greater load could be sustained. Record the maximum load applied to the cube. The compressive strengths for the various concrete from control to the various replaced concrete partially replaced by sawdust were calculated and recorded as shown in table 15, using the expression

$$
\mathrm{Fcu}=\frac{\text { crushing load }(\mathrm{N})}{\text { surface area }\left(\mathrm{mm}^{2}\right)} \text { for the mean crushing load. }
$$

\section{RESULTS AND DISCUSSION}

\section{Specific Gravity and Sieve Analysis of the Constituent Materials}

The average specific gravity of cement, sand, gravel and the sawdust ash used were $3.09,2.65,2.76$ and 0.68 respectively. The results of sieve analysis of the aggregates are shown in table 1 and 2 respectively. The result was used to calculate fine aggregate Fineness Modulus $(\mathrm{FM})=$ cumulative percentage retained up to standard sieve of size $150 \mu \mathrm{m} / 100=(1.16+5.08+19.59+44.82+61.68+95.08) / 100=2.27$, which is within the acceptable limit set for FM between 2.3 and 3.1 for ASTM range set for fine aggregates.

Table 1: Sieve Analysis Result for Fine Aggregate (Sand)

\begin{tabular}{|c|c|c|c|c|}
\hline $\begin{array}{c}\text { Sieve sizes } \\
(\mathrm{mm})\end{array}$ & $\begin{array}{c}\text { Mass Retained } \\
(\mathrm{g})\end{array}$ & $\begin{array}{c}\text { \% Retained } \\
\text { (weight) }\end{array}$ & $\begin{array}{c}\text { Cumulative \% } \\
\text { retained }\end{array}$ & $\begin{array}{c}\text { Cumulative } \\
\text { \% Passing } \\
\text { (weight) }\end{array}$ \\
\hline 4.75 & 5.8 & 1.16 & 1.16 & 98.94 \\
\hline 2.36 & 19.4 & 3.88 & 5.08 & 94.96 \\
\hline 1.18 & 72.7 & 14.54 & 19.59 & 80.42 \\
\hline 0.600 & 126.2 & 25.24 & 44.82 & 55.18 \\
\hline 0.300 & 84.3 & 16.86 & 61.68 & 38.32 \\
\hline 0.150 & 167 & 33.40 & 95.08 & 4.92 \\
\hline 0.075 & 18.2 & 3.64 & 98.72 & 0.0 \\
\hline Pan & 6.4 & 1.28 & 100 & \\
\hline$\Sigma$ & 500 & & & \\
\hline
\end{tabular}


Table 2: Sieve Analysis for $3000 \mathrm{~g}$ of coarse aggregate

\begin{tabular}{|c|c|c|c|c|}
\hline $\begin{array}{c}\text { Sieve Sizes } \\
(\mathrm{mm})\end{array}$ & $\begin{array}{c}\text { Mass } \\
\text { Retained }(\mathrm{g})\end{array}$ & $\begin{array}{c}\text { \% } \\
\text { Retained }\end{array}$ & $\begin{array}{l}\text { Cumulative } \\
\text { \% retained }\end{array}$ & $\begin{array}{c}\text { Cumulative } \\
\text { Passing }\end{array}$ \\
\hline 80.00 & 0.00 & 0.00 & 0.00 & 100.00 \\
\hline 40.00 & 150.00 & 5.00 & 5.00 & 95.00 \\
\hline 20.00 & 1100.00 & 36.67 & 41.67 & 58.33 \\
\hline 10.00 & 910.00 & 30.33 & 72.00 & 28.00 \\
\hline 4.75 & 840.00 & 28.00 & 100.00 & 0.00 \\
\hline 2.36 & 0.00 & 0.00 & 100.00 & 0.00 \\
\hline 1.18 & 0.00 & 0.00 & 100.00 & 0.00 \\
\hline 0.600 & 0.00 & 0.00 & 100.00 & 0.00 \\
\hline 0.300 & 0.00 & 0.00 & 100.00 & 0.00 \\
\hline 0.150 & 0.00 & 0.00 & 100.00 & 0.00 \\
\hline Pan & 0.00 & 0.00 & 100.00 & \\
\hline
\end{tabular}

According to the result of sieve analysis of the coarse aggregates in table 2, Fineness Modulus $(\mathrm{FM})=$ sum of cumulative percentage retained on the sieves $/ 100=$ $(5.00+41.67+72.00+100.00+100.00+100.00+100.00+100.00+100.00) / 100=718.67 / 100$ $=7.19$, which is within the acceptable limit set for FM between 5.5 and 8.0 for coarse aggregate by ASTM.

\section{Workability of Fresh Concretes}

The following results shown in Table 3 and figure 1 were obtained from the cone slump test having height $300 \mathrm{~mm}$ performed within 2 minutes of batching and mixing.

Table 3: Cone Slump and Self Compacting Concrete Test Result

\begin{tabular}{|c|c|c|}
\hline$\%$ Sawdust ash replaced & $\begin{array}{c}\text { Height of concrete } \\
(\mathrm{mm})\end{array}$ & $\begin{array}{c}\text { Slump of concrete } \\
(\mathrm{mm})\end{array}$ \\
\hline $0 \%$ sawdust Ash & 240 & 60 \\
\hline $5 \%$ sawdust Ash & 230 & 70 \\
\hline $10 \%$ sawdust Ash & 211 & 89 \\
\hline $15 \%$ sawdust Ash & 240 & 60 \\
\hline $20 \%$ sawdust Ash & 245 & 55 \\
\hline $25 \%$ sawdust Ash & 253 & 47 \\
\hline
\end{tabular}




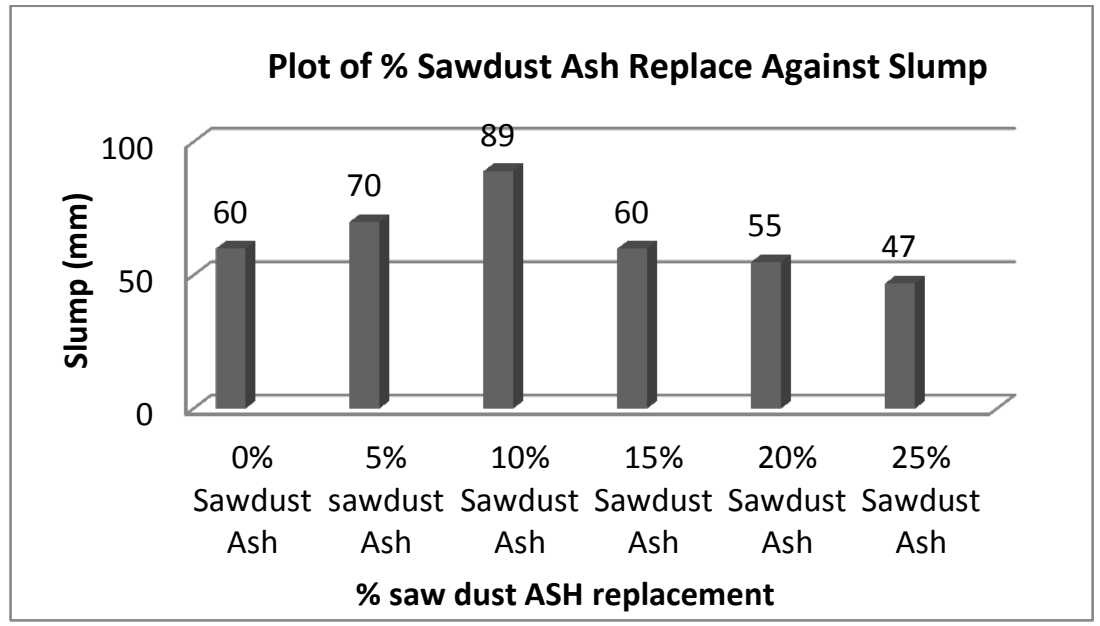

Figure 1. Results for Slump Test

\section{Hardened Concrete Tests}

The types of hardened concrete tests done were water absorption and destructive compressive strength tests.

\section{Water Absorption of Concrete}

The total increase of water absorption percentage from 0.82 to 2.24 with $0 \%$ to $25 \%$ SDA replacement respectively at 28 days of curing indicates high rate of sawdust ash water absorption. Fig. 2 showed maximum water absorption of 2.24 which is within the permissible rage of $1-4$ for fcu $25 \mathrm{~N} / \mathrm{mm}^{2}$ concrete.

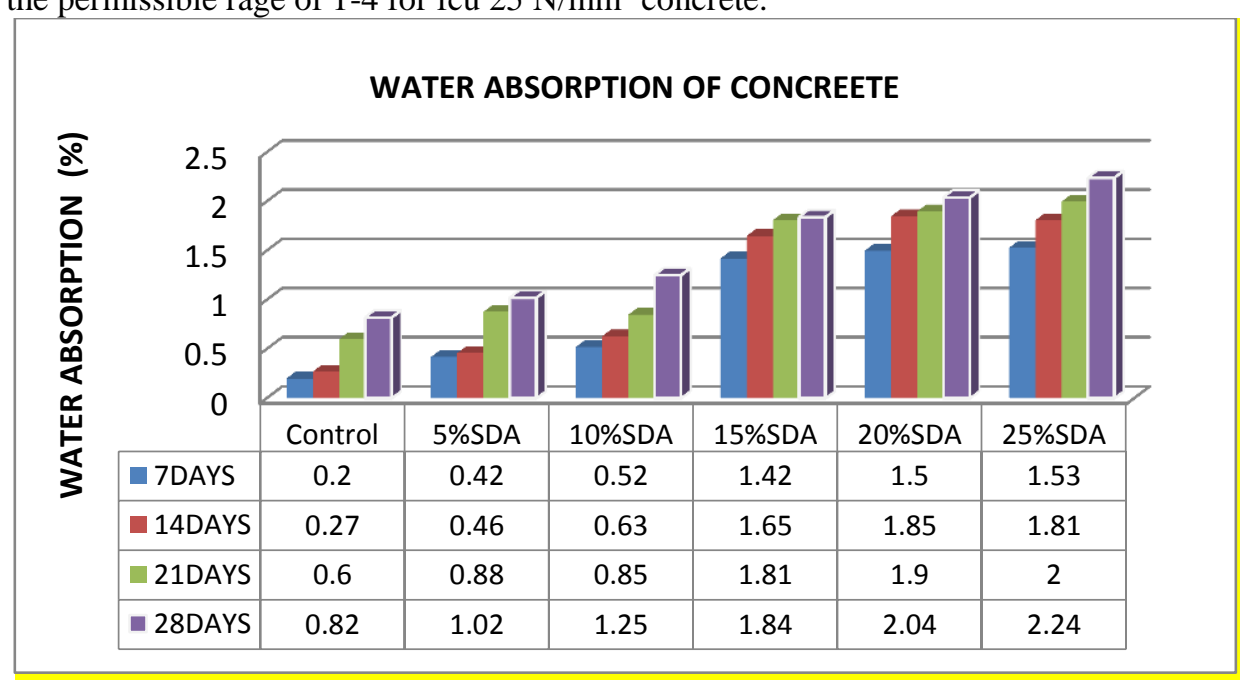

Figure 2: Water Absorption of Concretes at 7 to 28 days Curing 


\section{Compressive Strength of Concrete}

Table 4: Compressive Strength of Concrete Cubes

\begin{tabular}{|c|c|c|c|c|c|c|}
\hline $\begin{array}{l}\text { Day of } \\
\text { Curing }\end{array}$ & $\begin{array}{r}0 \% \\
\text { sawdust } \\
\text { ash } \\
\left(\mathrm{N} / \mathrm{mm}^{2}\right)\end{array}$ & $\begin{array}{l}5 \% \\
\text { sawdust } \\
\text { ash } \\
\left(\mathrm{N} / \mathrm{mm}^{2}\right)\end{array}$ & $\begin{array}{l}10 \% \\
\text { sawdust } \\
\text { ash } \\
\left(\mathrm{N} / \mathrm{mm}^{2}\right)\end{array}$ & $\begin{array}{l}15 \% \\
\text { sawdust } \\
\text { ash } \\
\left(\mathrm{N} / \mathrm{mm}^{2}\right)\end{array}$ & \begin{tabular}{l}
\multicolumn{1}{c}{$20 \%$} \\
sawdust \\
ash \\
$\left(\mathrm{N} / \mathrm{mm}^{2}\right)$
\end{tabular} & $\begin{array}{c}25 \% \\
\text { sawdust } \\
\text { ash } \\
\left(\mathrm{N} / \mathrm{mm}^{2}\right)\end{array}$ \\
\hline $7 D A Y S$ & 20.89 & 20.78 & 18.67 & 16.00 & 13.44 & 11.88 \\
\hline $14 D A Y S$ & 25.56 & 24.89 & 20.00 & 16.22 & 13.78 & 13.00 \\
\hline $21 D A Y S$ & 26.67 & 26.22 & 20.56 & 19.11 & 17.56 & 16.67 \\
\hline $28 D A Y S$ & 27.67 & 27.22 & 21.22 & 20.00 & 18.89 & 18.33 \\
\hline
\end{tabular}

The compressive strength of the sample using 0\% replacement (control) at 7 days was calculated thus; $\mathrm{Fcu}=\frac{470 \times 1000(\mathrm{~N})}{150 \times 150\left(\mathrm{~mm}^{2}\right)}=20.89 \mathrm{~N} / \mathrm{mm}^{2}$.

Also, other compressive strengths were calculated in similar manner and recorded. As shown in table 4 and figure 3, the compressive strengths have a progressive strength growth from 7day - 28day. At $7^{\text {th }}$ day, the control had the highest value followed by the $5 \%$ concrete and down from $10 \%$ replacement to $25 \%$. At 28 days curing, the control and $5 \%$ replacement level had exceeded the target mix design of $25 \mathrm{~N} / \mathrm{mm}^{2}$ thus notifying that the mix at 0.5 water-cement ratio was adequate. Also at this 28 days, the remaining concrete from $10 \%, 15 \%, 20 \%$ and $25 \%$ respectively meet up with the stipulated strength for light weight structural concrete with strength of 17 to $63 \mathrm{MPa}$ according to [20].

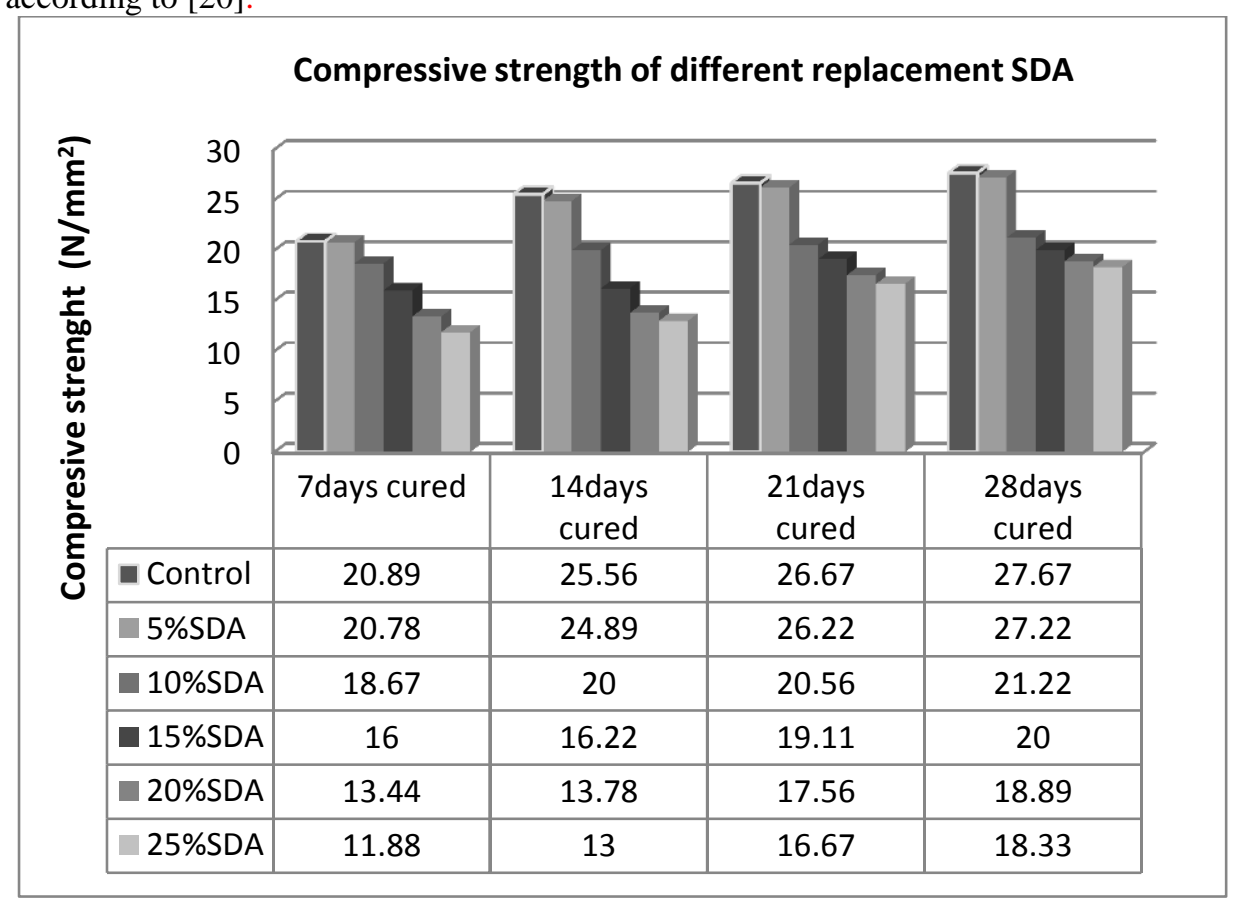

Figure 3: Compressive Strength of Concrete at 7-28 Days Curing $\left(\mathrm{N} / \mathrm{mm}^{2}\right)$ 


\section{CONCLUSION}

The project on the application of industrial waste (sawdust) in concrete production yielded good results. It has proven to be a good pozzolan, hence it can be used to improve the properties of concrete in terms of workability and durability. It was discovered that it is applicable in the production of light weight concrete structures at $10 \%$ and above in partial replacement of cement with sawdust ash. The use of Sawdust has economic benefit, environmental benefit and technical benefits. It is seen as waste to wealth initiation in agriculture and concrete industry.

The use of Gmelina arborea Roxb.,sawdust ash as partial replacement with $10 \%$ to $25 \%$ of OPC in concrete can be useful in farm structures for Foundation walls; basement walls; structural concrete; walls; reinforced floor slabs; floors for dairy and beef cattle, pigs and poultry; floors in grain and potato stores, hay barns, and machinery stores; septic tanks and water storage tanks; slabs for farmyard manure; roads, driveways, paving and walks; stairways.

Also, 5\% partial replacement of cement with Gmelina arborea Roxb., sawdust ash can yield a target strength of concrete grade $\mathrm{C} 25$, and applicable for All concrete in milking parlours, dairies,silage silos, and feed and drinking troughs; floors subject to severe wear and weather conditions, or weak acid and alkali solutions; roads and paving in frequent use by heavy machinery and lorries; small bridges; retaining walls and dams; suspended floors, beams and lintels; floors used by heavy,small-wheeled equipment, such as lift trucks; fencing posts and precast concrete components.

\section{BIBLIOGRAPHY}

[1] ASTM C618-15,. 2015. Standard Specification for Coal Fly Ash and Raw or Calcined Natural Pozzolan for Use in Concrete, ASTM Int., West Conshohocken. PA, www.astm.org

[2] Moore and David . 2013. "The Riddle of Ancient Roman Concrete". S Dept. of the Interior, Bureau of Reclamation, Upper Colorado Region. www.romanconcrete.com. Retrieved 20 May 2013.

[3] Adesanya, D. A. and Raheem, A. A. 2009. Development of Corn Cob Ash Blended Cement Construction and Building Materials, 23, 348-352.

[4] Hussein, A. A., Shafiq, N., Nuruddin, M. F. and Memon, F. A. 2014. Compressive Strength and Microstructure of Sugar Cane Bagasse Ash Concrete. Research Journal of Applied Sciences, Engineering and Technology. 7, 2569-2577

[5] Mahmoud, H., Belel, Z.A. and Nwakaire, C. 2012. Groundnut Shell Ash as a Partial Replacement of Cement in Sandcrete Blocks Production. International Journal of Development and Sustainability 1, 1026-1032

[6] Etuk, B. R., Etuk, I. F. and Asuquo, L. O. 2012. Feasibility of Using Sea Shells Ash as Admixtures for Concrete. Journal of Environmental Science and Engineering, A1, 121-127

[7] Jayasankar R, Mahindra N and Ilangovan R. 2010. Studies on Concrete using Fly Ash, Rice Husk Ash and Egg Shell Powder. International Journal of Civil and Structural Engineering. Vol.1. No3. ISSN 0976-4399. pp.362-372.

[8] Godwin A. Akeke, Maurice E., Ephraim, Akobo, I.Z.S and Joseph O. Ukpata. 2013 Structural Properties of Rice Husk Ash Concrete. International Journal of Engineering and Applied Sciences, 3(3). pp.57-62.

[9] Marthong C. 2012. Effect of Rice Husk Ash (RHA) as partial replacement of Cement on Concrete Properties. International J. of Engineering Research \& Techn.. ISSN: 2278-0181 Vol.01 (06). pp.1-7. 
[10] Boateng A.A., Skeete D.A. 1990. Incineration of Rice Hull for use as a Cementitious Material". Cement and Concrete Research 20(5), pp. 795 - 802.

[11] Cook D.J. 1984. Development of Microstructure and Other Properties in Rice Husk AshOPC Systems". Proceedings of $9^{\text {th }}$ Australian Conference Mechanics of Structures and Materials. Sydney, $325-338$.

[12] Hossain, K. M. A. 2003. Blended Cement using Volcanic Ash and Pumice. Cement and Concrete Research, Vol. 33, pp. 1601-1605.

[13] ASTM C33 / C33M-18. 2018. Standard Specification for Concrete Aggregates. ASTM International, West Conshohocken, PA. www.astm.org

[14] British Standard Institution . 2000. Specification for Portland cement. BS EN 197-1, British Standard Institution. London.

[15] British Standard Institution. 2002. Methods of test for water for making concrete, BS EN 1008, British Standard Institution. London.

[16] ASTM C143 / C143M-15a. 2015. Standard Test Method for Slump of Hydraulic-Cement Concrete, ASTM International, West Conshohocken, PA. www.astm.org

[17] Geoffrey C. Mrema, Lawrence O. Gumbe, Hakgamalang J. Chepete and Januarius O. Agullo. 2011. Rural Structures in the Tropics; Design and Development. Food and Agriculture Organization of the United Nations Rome,. pp. 72.

[18] ASTM C 1585-13. 2013. Standard Test Method for Measurement of Rate of Absorption of Water by Hydraulic-Cement Concretes. ASTM Int.1,West Conshohocken,PA, www.astm.org

[19] British Standard 1881: part116 .1983. Method for Compressive Strength of Concrete Cubes. British Standard Institute, British Stan. Board, 389 Chriswick High Road, London W4 4AL.

[20] ACI 213R-14. 2014. Guide for Structural Lightweight Aggregate Concrete. American Concrete Institute, Detroit. Michigan,USA.

\title{
STUDIJA UPOTREBE PEPELA PILJEVINE DRVETA Gmelina arborea Roxb. KAO DODATAKA U PROIZVODNJI BETONA U DRŽAVI ABIA, NIGERIJA
}

\author{
Oluwaseun Babalola $^{1 *}$, Michael Etteben ${ }^{2}$, Nkiru Ezejiofor ${ }^{3}$, \\ Nnaemeka Nneji ${ }^{4}$, David Eze ${ }^{5}$, Francis Orji ${ }^{6}$, Augustine Igbozulike ${ }^{7}$
1, 2,4,5,6,7 Michael Okpara University of Agriculture, Umudike, Nigeria ${ }^{3}$ National Agricultural Extension Research and Liaison Service, Ahmadu Bello University, Zaria, Nigeria

Sažetak. Gmelina arborea Roxb., je stablo kišne prašume koje se nalazi u tropskom regionu Nigerije. Studija istražuje izvodljivost i uticaj na osobine betona korišćenjem pepela od piljevine stabla Gmelina arborea Roxb., u državi Abia, Nigerija.

Korišćena je betonska mešavina 1:2:4 zapreminskog odnosa i konstantni odnos vode prema cementu od 0,6 .

\footnotetext{
* Correspondeng author. E-mail address. ojedelestephen@gmail.com
} 
Testovi su od 60, 70, 89, 60, 55 i $47 \mathrm{~mm}$ uz delimičnu nadoknadu od 0, 5, 10, 15, 20 i $25 \%$ dodatka (sadržaj pepela). Vrednosti uzoraka na pritisak posle 28-og dana od očvršćivanja za dodatke od $0,5,10,15,20$ i $25 \%$ bila je 27.67, 27.22, 21.22, 20.00, 18.89 i $18.33 \mathrm{~N} / \mathrm{mm}^{2}$ retrospektivno.

Istraživanje \% zamene (dodatka) pokazuje da sve ispitivane vrednosti zamene imaju dobre osobine i mogu se kategorisati kao dobro poboljšanje mešavine, pri čemu $10 \%$ delimična zamena (dodatak pepela) daje najbolje osobine betona.

Pored toga, čvrstoća betona na pritisak dobijena posle 28. dana pokazuje da beton razvija dobru čvrstoću, koja se može povećavati u narednim godinama, jer pozolanski beton razvija kasnije bolju pritisnu čvrstoću (tvrdoću) i izdržljivost od običnog (standardni) betona.

Ključne reči: Stablo Gmelina arborea Roxb., pepeo od piljevine, puzolan, beton, obradivost, pritisna čvrstoća

Prijavljen:

Submitted: 28.10.2019.

Ispravljen:

Revised:

06.02.2020

Prihvaćen:

Accepted:

09.03.2020. 